\title{
粒径分布をもつ固体粒子浮游による傾斜サ一マルの解析法 ANALYSIS OF INCLINED SUSPENSION THERMAL WITH NONUNIFORM PARTICLES
}

\author{
福嶋祐介 ${ }^{1}$ ・ 今田昌運 ${ }^{2}$ \\ Yusuke FUKUSHIMA and Masayuki IMADA \\ ${ }^{1}$ 正会員 長岡技術科学大学教授 工学部環境・建設系（广940-2188 長岡市上富岡町 1603-1） \\ ${ }^{2}$ 工修 (株) エイエスシビルコンサルタント（† 733-0025 広島市西区小河内 2-23-8)
}

\begin{abstract}
The experiments on the non-conservative inclined wall thermals using the mixture of water and nonuniform barium sulfate particles are carried out. The experimental results obtained may be compared with the numerical simulations. The new numerical model of an inclined wall thermal is proposed, in which the size distribution of solid particles is taken into account. The simulation model for inclined wall thermals of nonuiform suspended particles consists of the continuity equation, the mass conservation equation and the momentum equation. In the model, the dimensionless value $\alpha$ related to the entrainment coefficient $E_{w}$ and the form drag coefficient $c_{D}$ are chosen as parameters. Comparing the numerical calculation with experimental results of inclined thermals, likely values of $\alpha$ and $c_{D}$ are obtained.
\end{abstract}

Key Words : inclined thermal, suspension flow, nonuniform solid particles, size distribution numerical analysis

\section{1. はじめに}

傾斜壁面サーマル(以下サーマル) は重力流の代表例 であり，自然界で多く観測される。例えば，厳冬期山岳 地帯で発生する煙型雪崩, 海底や湖沼で発生する泥水 流などである，傾斜サーマルは，溶解性物質によって 形成され，負の浮力の総量が保存される “保存性傾斜 サーマル”と，固体粒子の浮游などで形成され，負の浮 力の総量が保存されない “非保存性傾斜サーマル”とに 分類される.

保存性の重力密度流についてはこれまでに多くの研 究がある. Beghin and Olagne ${ }^{1)}$ は三次元の傾斜サーマ ルの実験と理論的検討を行っている. 上石・川田 ${ }^{2)}$ は塩 水を用いた傾斜プルームの実験を行っている. 福嶋・早 川・山口 ${ }^{3}$ は塩水を用いた傾斜プルームの実験を行い, 二次元傾斜プルームの理論との比較を行っている.こ れらの研究は何れも煙型雪崩の模擬実験として行われ たものである.

一方，非保存性のサーマルの流動機構を考慮するた めには，固体粒子の特性を十分に考虑することが必要 である. 特に粒径はその大きさによって静水中の沈降速 度が変化することから，サーマルの流動に与える影響 は大きい. 浮游粒子の流体力学特性を考慮した傾斜サ一 マルの研究はあまり多くはない．著者ら(福嶋・金子4), 福嶋・萩原 ${ }^{5)}$, 福嶋・萩原・坂本 ${ }^{6)}$ ) は固体粒子の沈降を 考慮したサーマルの理論を提案し, 害験を行いその結 果と数值解析結果と比較してきた. これらの研究では 粒子の直径を平均粒径で代表させている. 一方, 粒径

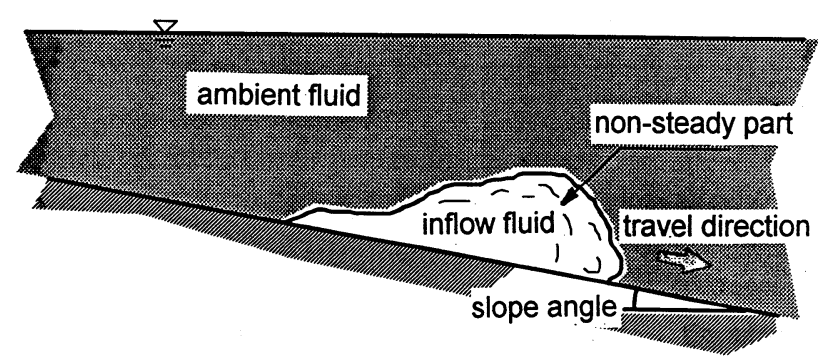

図 1: 傾涂壁面斜サーマルの模式図

の大きさは沈降速度と密接に関わっており，その分布 (particle size disribution) を考慮することは浮游サーマ ルの流動機構をより深く解明する上で重要であると考 えられる。

本研究では, 淡水中に塩水あるいは硫酸バリウ ム (以下バリウム)混合水を流下させ, 二次元的に 非保存性サーマルを実験で再現し, 沈降した粒子 の粒径分布を測定した。さらに, 粒度分布を考慮 した新しい流動モデルを提案した。さらにこのモ デルを用いて数值解析した結果を実験結果と比較 することによって，モデルの妥当性を検討した。

\section{2. 実験装置及び実験方法}

測定項目として従来の研究で測定されてきたサーマ ルの流下特性, 流動特性とともに硫酸バリウム粒子の 沈降量とその粒径分布も測定した. コールターカウン 


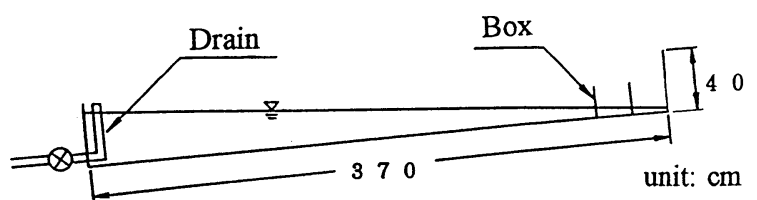

(a) Experimental Apparatus (1)

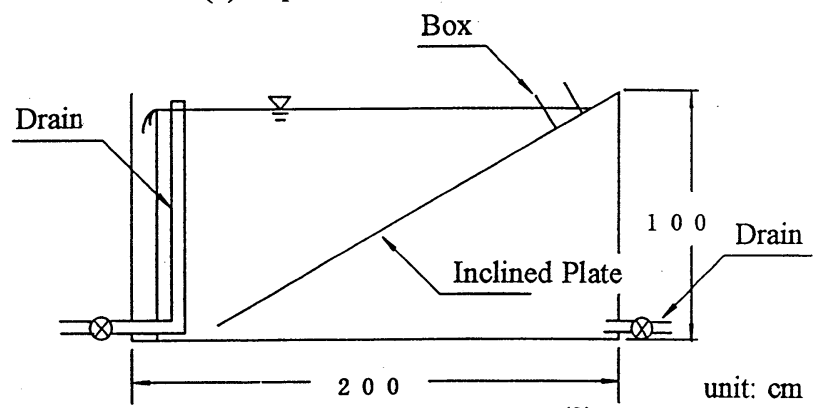

(b) Experimental Apparatus (2)

図 2: 実験装置 $(\mathrm{a})$ と (b).

表 1：実験条件

\begin{tabular}{|c|c|c|c|c|c|}
\hline $\begin{array}{c}\text { Run } \\
\text { No. }\end{array}$ & $\begin{array}{c}\text { slope } \\
\left({ }^{\circ}\right)\end{array}$ & $\begin{array}{c}\text { Initial C. } \\
C_{0}(\%)\end{array}$ & $\begin{array}{c}\text { Temp. } \\
{ }^{\circ} C\end{array}$ & $\begin{array}{c}\rho_{a} \\
\left(\mathrm{~g} / \mathrm{cm}^{3}\right)\end{array}$ & $\begin{array}{c}\Delta \rho / \rho_{a} \\
(-)\end{array}$ \\
\hline 1 & 10.0 & 5.0 & 11.0 & 0.99961 & 0.04014 \\
2 & 10.0 & 20.0 & 13.0 & 0.99938 & 0.18261 \\
3 & 30.0 & 5.0 & 14.0 & 0.99924 & 0.04017 \\
4 & 30.0 & 20.0 & 14.5 & 0.99917 & 0.18279 \\
\hline
\end{tabular}

ターにより沈降した硫酸バリウム粒子の粒径分布を測 定した.これらの実験ではサーマルの流下速度を大き くするため, バリウムの濃度を大きくした場合の実験 を行った.

傾斜壁面サーマ川の模式図を図 1に示寸，実験は斜面 の傾斜角が $10^{\circ}$ と $30^{\circ}$ の 2 種類で行った. 傾斜角 $10^{\circ}$ の実 験では図 $2(\mathrm{a})$ の水槽を用いた。この水槽は長さ $370 \mathrm{~cm}$, 高さ $40 \mathrm{~cm}$ ，幅 $15 \mathrm{~cm}$ のアクリル製である. また傾斜角 $30^{\circ}$ の場合では, 図 $2(\mathrm{~b})$ に示す, 水路長 $200 \mathrm{~cm}$, 高さ $100 \mathrm{~cm}$, 水路幅 $30 \mathrm{~cm}$ のアクリル製水槽に幅 $15 \mathrm{~cm}$ のア クリル板を傾斜角 $30^{\circ}$ に固定したものを用いた.

サーマルによる流れ場を調べるため硫酸バリウム混 合水による非保存性傾斜サーマルの実験を行った。淡 水を満たした水槽上部のボックスに硫酸バリウム混合

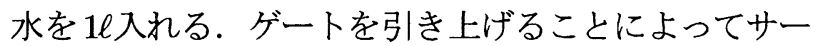
マルを発生させる. その流れをビデオカメラで撮影し, 最大厚さ, 流下速度を測定した. サーマルとして流下す る硫酸バリウム粒子量 (以下では “サーマル量”と呼ぶ) を測定するため, ボックス内と流下方向に $20 \mathrm{~cm}$ 間隔で バリウム粒子をサイフォンで採取し，それぞれの区間 での沈降量 $B_{f i}$ を求めた. サーマル量はボックスから浮 遊して流下したバリウム量 $B a_{0}$ からそれぞれの区間で の沈降量 $B a_{i}$ を差し引くことにより求めた. すなわち $i$ 番目の区間のサーマル量は $B a_{i}=B a_{i-1}-B_{f i}$ となる. バリウム粒子の粒径分布の測定では, 各区間で沈降し た硫酸バリウム粒子のサンプルを粒径測定装置コール ターカウンターを用いて測定した．なお，硫酸バリウ ムの比重は4.37であった。

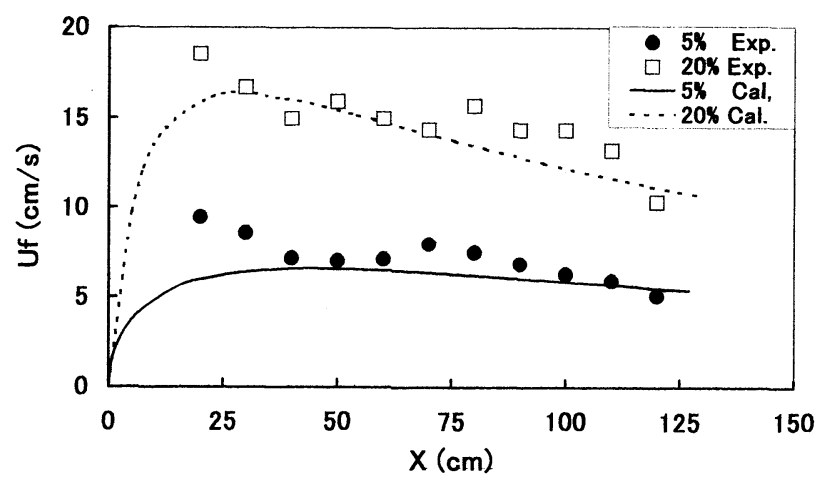

図 3: 流下速度の流下距離に対する変化, $\theta=10^{\circ}$, Run $1\left(C_{0}=5 \%\right)$, Run $2\left(C_{0}=20 \%\right)$

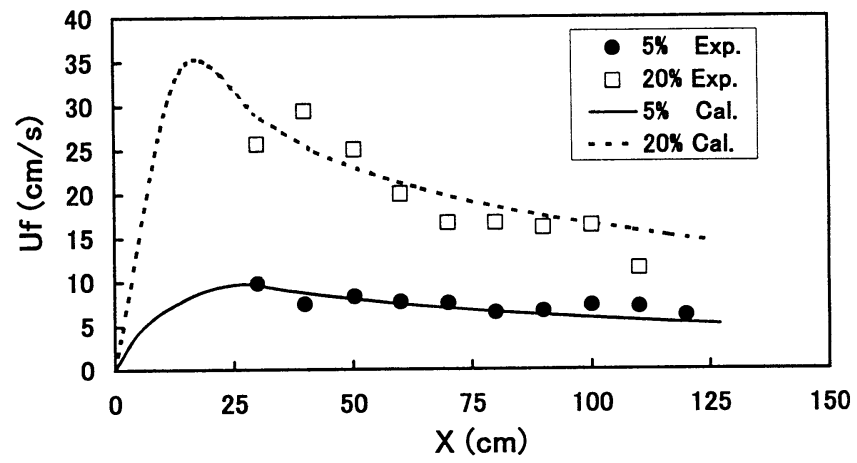

図 4: 流下速度の流下距離に対する変化, $\theta=30^{\circ}$, Run $3\left(C_{0}=5 \%\right)$, Run $4\left(C_{0}=20 \%\right)$

本研究で対象とした実験条件を表 1 にまとめて示す.

\section{3. 実験結果とその考察}

流下距離に対するサーマルの流下速度の変化を図 3,4 に示す．実験值を記号で後述する数值解析結果を曲線 で示している. サーマルの流下速度は初期濃度が増加 すると大きくなり，流下距離が大きくなるに従って流 下速度が減少する．初期濃度が大きくなるとサーマル 内の負の浮力が増えるため, 流下速度が増加すると考 えられる.また，周囲水の連行やバリウム粒子の沈降 により負の浮力が減少することに対応して，サーマル の流下速度が流下方向に減少したものと考えられる.

流下距離に対するサーマル量の変化を図 5 (Run 1,3 ), 6(Run 2,4) に示す.これらの図においても実験值を記 号で，数值解析結果を曲線で示した。ここで言うサー マル量は，ボックスに入れたバリウム量とその沈降量 の測定值から計算で求めたものである。図5から初期濃 度 $5 \%$ の場合では，流下距離に対するサーマル量の減少 割合が大きい. $\theta=30^{\circ}$ の場合の方が減少割合が小さい のは, $\sin \theta$ に比例して流下方向に働く重力の斜面方向 成分が大きくなるため，サーマル内の粒子がより遠く に運ばれたことが理由としてが考えられる. 図6の初期 濃度が $20 \%$ の場合では，傾斜角の違いによってサーマ ル量の差が全体的に大きくなっている．これは傾斜角 $30^{\circ}$ ，初期濃度 $20 \%$ の実験条件(Run 4) では，流入ボッ 


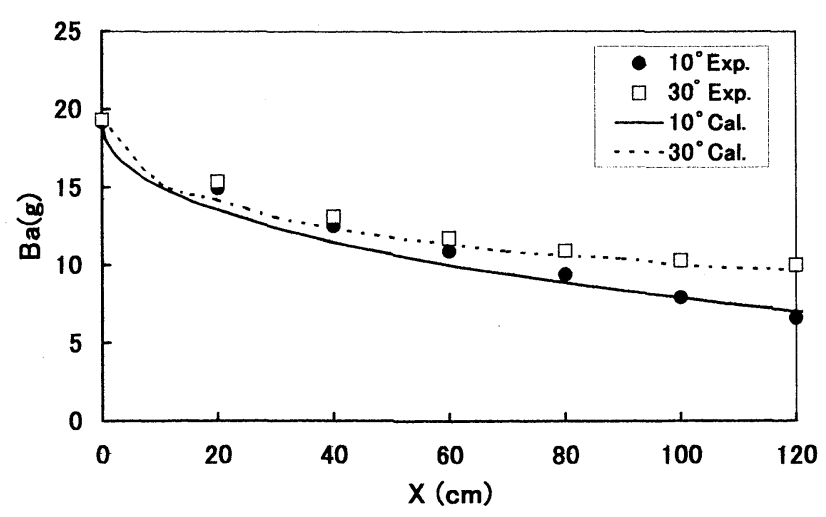

図 5: サーマル量の流下距離に対する変化, $C_{0}=5 \%$, Run $1\left(\theta=10^{\circ}\right)$, Run $3\left(\theta=30^{\circ}\right)$.

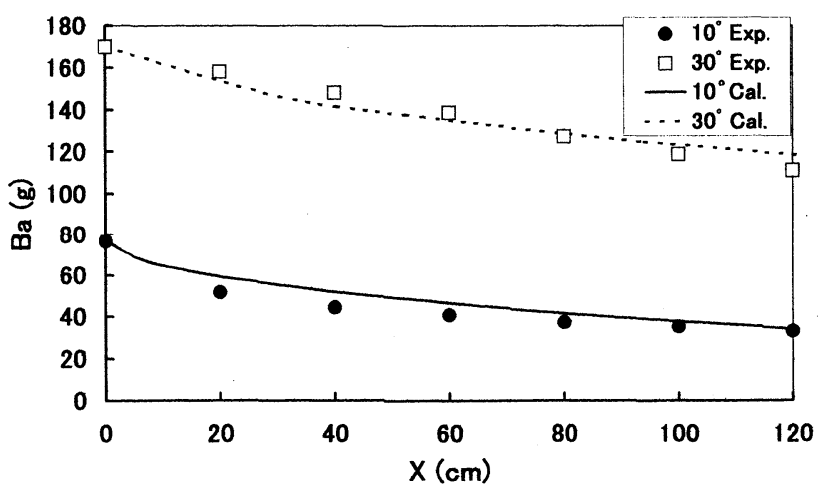

図 6: サーマル量の流下距離に対する変化, $C_{0}=20 \%$, Run $2\left(\theta=10^{\circ}\right)$, Run $4\left(\theta=30^{\circ}\right)$.

クスの傾きが大きく，流入ゲート付近に硫酸バリウム粒 子が多く堆積していたバリウムがゲート開放直後, 混 合水の流下に伴って多量に流出したためである. この理 由により $\theta=30^{\circ}$ では，サーマル量がかなり大きくなっ たものである.

実験に用いた硫酸バリウムの粒径を粒径測定装置コー ルターカウンターZM型によって測定した結果を図7に 示す. 粒度比とは各粒径範用で測定した個数と全測定個 数との割合を表したものである.また，各区間で沈降し たバリウム粒子の粒径分布変化を図 8(Run 3), 9(Run 4)に示す.このケース Run 3, Run 4 では, 粒径が大き いほど沈降速度が大きくなるため，流下方向に大きな 粒径の粒子の割合が減少し，小さな粒径の粒子の割合 が増加する傾向にある。これは，大きな粒径の粒子は 静水中での沈降速度が大きく沈降しやすいが，小さな 粒径の粒子は沈降速度が小さく沈降しにくいためであ る.しかしながら，今回の実験で得られた条件では粒 子の沈降速度に大きな差がなかったため粒度分布の流 下方向の変化については顕著な傾向は見られなかった。

\section{4. 粒径分布を考慮した傾斜サーマルの流動モデル}

著者らが進めてきた傾斜壁面浮游サーマルの流動モ デル4),5),6)を発展させ，固体粒子の粒度分布を考慮でき るように改良した。流動モデルの基本的な構成はサー

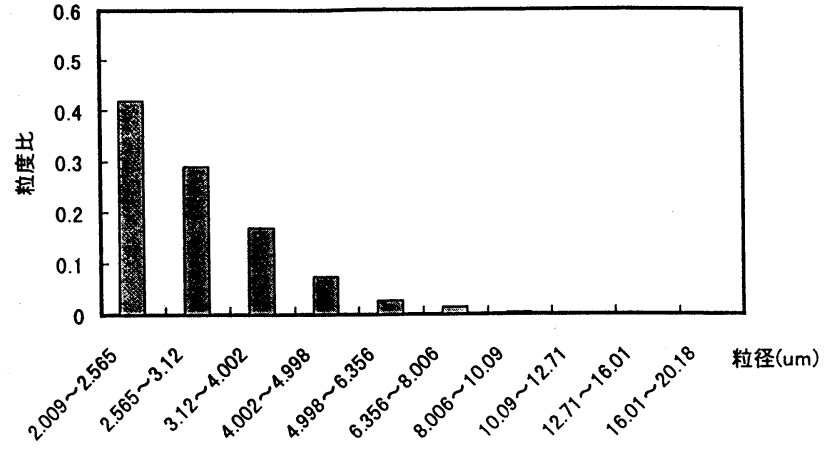

図 7: 硫酸バリウムの粒径分布

マルの体積の連続式と流下方向の運動方程式, 粒径分 布を考慮した固体粒子の輸送方程式である.モデルを 構築する上での仮定は基本的にはこれまでのものと同 一であり，連続式，運動方程式に変更点はない。

傾斜サーマルの模式図と記号を図 10 に示す. 斜面の傾 斜角を $\theta$, 周囲流体の密度を $\rho_{a}$, サーマルの平均密度を $\rho$, サーマルの層厚を $h$, サーマルの断面積を $A$, サー マルフロントの流下速度を $U_{f}$, 底面の長さを $P_{b}$, サー マルの周囲流体と境界面との長さ (潤辺長)を $P_{i}$, サー マルの流下距離を $s$, 重力加速度を $g$ とする.

福嶋らの一様粒径を仮定した前回までのモデル5),6) に対して、今回新たに固体粒子が粒径分布を考慮した 解析法を提案する. 固体粒子の粒径分布が全体で $n$ 個 の範囲で分割する. その中で $k$ 番目の粒径区分の体積濃 度を $C_{k}$, 底面近傍の濃度を $c_{b k}$ とする. 体積濃度の総和 をCで，また底面近傍の濃度を $c_{b}$ で表すと次のように なる.

$$
C=\sum_{k=1}^{n} C_{k} ; \quad c_{b}=\sum_{k=1}^{n} c_{b k}
$$

混合水としての密度 $\rho$ はを用いて次のように書ける.

$$
\rho=\rho_{a}+\left(\rho_{s}-\rho_{a}\right) C=\rho_{a}(1+R C)
$$

ここで，Rは固体粒子と周囲水の相対比重であり $R=$ $\left(\rho_{s}-\rho_{a}\right) / \rho_{a}$ となる. 周囲流体中での相対密度差 $\varepsilon$ はこの 相対比重差 $R$ と固体粒子の体積濃度 $C$ を用いて, $R C(=$ $\varepsilon)$ で表される.

福嶋7)が初めて示したように，サーマルの形状が斜 面の傾斜角によって相似であると仮定し，各種の形状 関数を用いて，サーマルの幾何学的な特性を表現する. この仮定は，福嶋ほか44),5),6)により，傾斜角 $\theta$ が $5^{\circ}$ 以上 で成立することが確かめられている，傾斜サーマルの 面積 $A$, 内部境界面の潤辺長 $P_{i}$, 底面の長さ $P_{b}$ は最大 厚さ $h$ の一義的な関数であり，これらに対する形状係数 $\xi_{A}, \xi_{i}, \xi_{b}$ を用いて次のように表す。

$$
A=\xi_{A} h^{2} ; \quad P_{b}=\xi_{b} h ; \quad P_{i}=\xi_{i} h
$$

今回の解析では新たに粒径分布を考慮した解析法を提 案しているが、モデルに含まれる形状係数について同 じ関数で評価するのに問題はないと考えた.

固体粒子の輸送方程式は，それぞれの粒径区分の粒 子に対して考慮する必要がある. すなわち， $k$ 番目の粒 

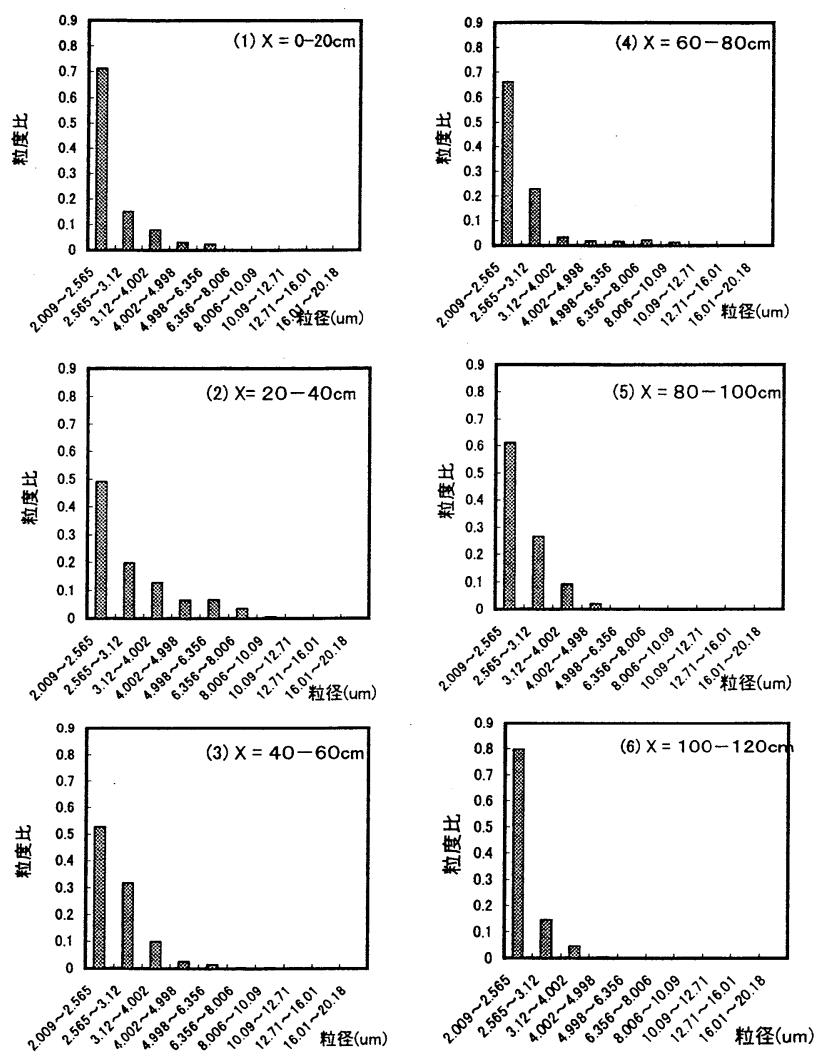

図 8: 流下距離 $20 \mathrm{~cm}$ ごとの粒径分布の変化, Run $3\left(C_{0}\right.$ $=5 \%, \theta=30^{\circ}$ ).

径区分に対する固体粒子の輸送方程式は次のように表 される.

$$
\frac{d}{d t} C_{k} A=v_{s k}\left(p_{k} E_{s k}-c_{b k} \cos \theta\right) P_{b}
$$

ここで, $t$ は時間, $v_{s k}, E_{s k}, c_{b k}$ はそれぞれ $k$ 番目の粒 径区分の沈降速度, 粒子の連行係数, 底面近傍の体積 濃度である. $p_{k}$ は流路床に堆積している全粒子に対す る $k$ 番目の粒子の割合である。 $k$ 番目の粒子に対する輸 送方程式は, 粒径区分の数の $n$ 本だけあることになる. 混合水の体積の保存式は次のようになる.

$$
\frac{d A}{d t}=E_{w} U P_{i}+\sum_{k=1}^{n} v_{s k}\left(p_{k} E_{s k}-c_{b k} \cos \theta\right) P_{b}
$$

ここで， $E_{w}$ は周囲流体の連行係数，Uはサーマルの質 量中心の移動速度である. 底面密度 $\rho_{b}$ と $c_{b}$ との関係は 次式で表される.

$$
\rho_{b}=\rho_{a}\left(1-c_{b}\right)+\rho_{s} c_{b}=\rho_{a}\left(1+R c_{b}\right)
$$

流下方向の運動方程式は次式で表される.

$\frac{d}{d t}\left(\rho+k_{v} \rho_{a}\right) U_{f} A=\left(\rho-\rho_{a}\right) g A \sin \theta-\tau_{i} P_{i}-\tau_{b} P_{b}-F_{D}$

ここで, $k_{v}$ は仮想質量係数, $U_{f}$ サーマルフロントの移 動速度, $g$ は重力加速度, $\tau_{i}, \tau_{b}$ は, それぞれ, 内部境 界面と底面に作用するせん断応力， $F_{D}$ はサーマルに作
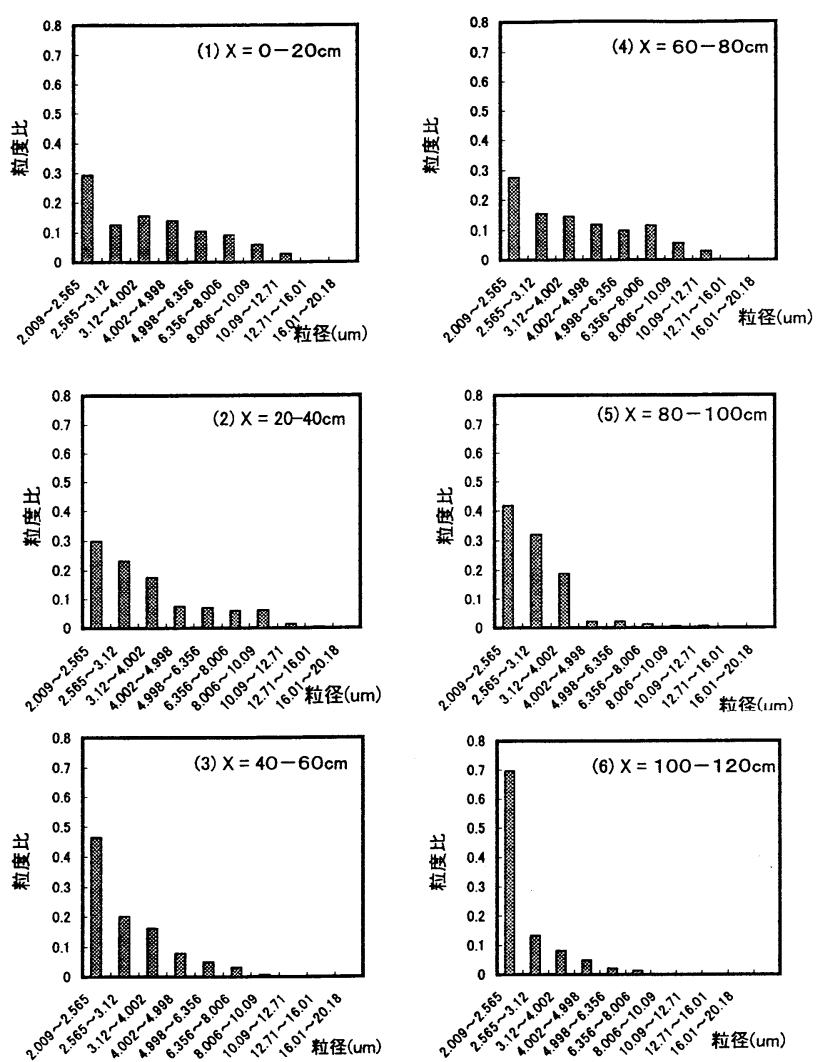

図 9: 流下距離 $20 \mathrm{~cm}$ ごとの粒径分布の変化, Run $4\left(C_{0}\right.$ $=20 \%, \theta=30^{\circ}$ ).

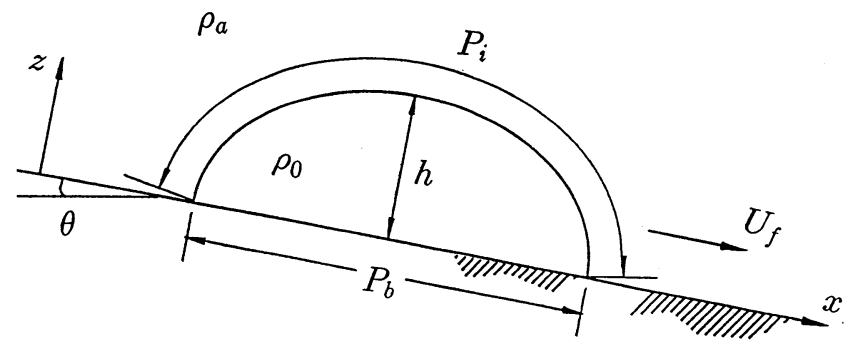

図 10: 傾斜壁面浮游サーマルの模式図と記号

用する抗力である. 式(4)，(5)，(7) が傾斜サーマルの 流動を表す基礎方程式である。これは主たる微分方程

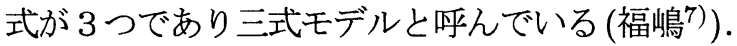

流動モデルを構築するために, 基礎方程式に加えて, 構成方程式が必要である. 内部境界面及び底面に作用 するせん断応力 $\tau_{i}, \tau_{b}$, フロントに作用する抗力 $F_{D}$ は, サーマルの質量中心の流下速度 $U$ とフロントの移動速 度 $U_{f}$ と次のように関係づけられる.

$$
\tau_{i}=f_{i} \rho_{a} \frac{1}{2} U^{2} ; \quad \tau_{b}=f_{b} \rho_{b} \frac{1}{2} U^{2} ; \quad F_{D}=c_{D} \rho_{a} \frac{1}{2} U_{f}^{2} h
$$

ここで， $f_{i}, f_{b}$ はそれぞれ，上部境界面と，底面での摩 擦抵抗係数, $c_{D}$ はフロントの抗力係数である.

フロントの形状係数及び仮想質量係数はフロントの 

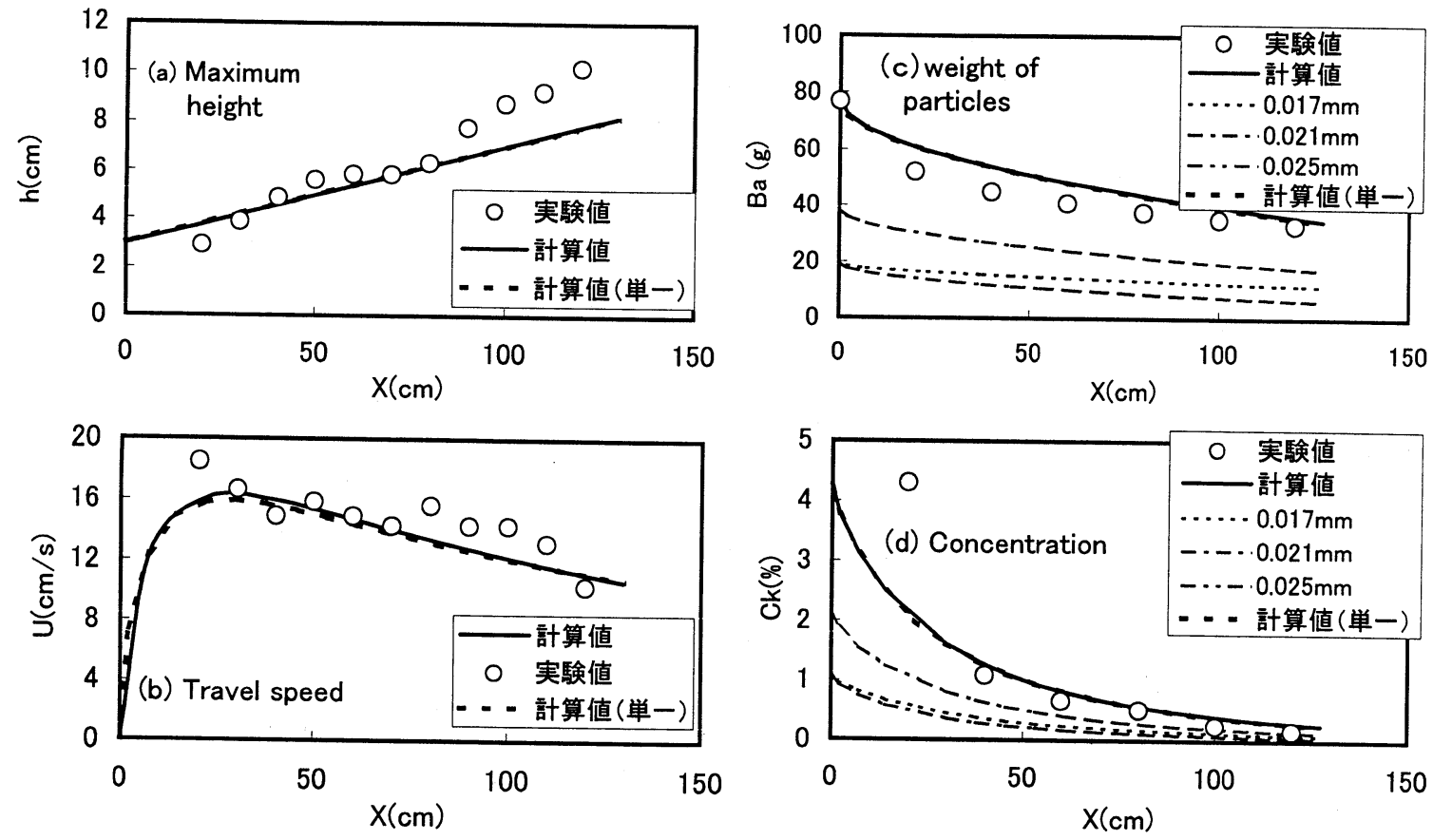

図 11: 計算結果と実験結果との比較 (Run $2, C_{0}=20 \%, \theta=10^{\circ}, \alpha=0.5, c_{D}=0.25$ )

形状が半楕円形で表される7) と考え，次のように表す.

$$
\xi_{A}=\frac{\pi}{4} \xi_{b} ; \quad \xi_{i}=\frac{\pi}{2 \sqrt{2}} \sqrt{\left(4 \xi_{b}^{-2}+1\right)} \xi_{b} ; \quad k_{v}=2 / \xi_{b}
$$

底面の長さに関連する形状係数 $\xi_{b}$ は，斜面の傾斜角 $\theta$ の 関数で与えられる. 福嶋 ()は次のような実験式を提案 した.

$$
\xi_{b}=8.47 \theta^{-1 / 3}
$$

ここで, $\theta$ は度 $\left(^{\circ}\right)$ で表される.

周囲流体の連行係数 $E_{w}$ は次式で表す。

$$
E_{w}=\alpha \frac{\theta}{90^{\circ}}
$$

ここで, $\alpha は \theta=90^{\circ}$ の場合の連行係数であり, 実験 結果との比較により定めるものとする. Escudier and Maxworthy ${ }^{8)}$ では, 規模の大きな鉛直三次元サーマル の場合で, $\alpha=0.1 \sim 0.25$ の值を報告している. 一方, 秋山ら ${ }^{9)}$ は室内実験による保存性の二次元サーマルに対 して $\alpha-0.4$ となることを報告している.

粒径分布を考慮した底面での固体粒子の連行係数 $E_{s k}$ はAkiyama and Fukushima ${ }^{10)}$, Garicia and Parker ${ }^{11)}$ により提案されているように粒径と底面せん断応力の 関数である. しかし，今回の比較に用いた実験では流 れの規模が小さいことから粒子の沈降が卓越した領域 にあり，底面からサーマルへの粒子の連行は無視でき るほど小さい. 一方, 流路床での固体粒子の堆積層が ないので $p_{k}=0$ である. この二つの理由で流路床から の粒子の巻き上げの項は零となる.

計算では, パラメータとして粒子の粒径を与える. 今 回の実験の範囲では粒子レイノルズ数が十分に小さく 沈降速度は次のストークスの式で求められる.

$$
v_{s k}=\left(\frac{\rho_{s}}{\rho_{a}}-1\right) g \frac{D_{s k}^{2}}{18 \nu}
$$

ここで， $D_{s k}$ は固体粒子の粒径， $v_{s k}$ は粒径 $D_{s k}$ の粒子 の静水中における沈降速度である.

\section{5．計算結果と実験値との比較}

数值計算にあたっては, 福嶋ら ${ }^{4), 5), 6)}$ の研究から, 鉛 直サーマルの連行係数 $\alpha$ を 0.5 , 抗力係数 $c_{D}$ を $0 \sim 0.5$ 之 すると良く適合することが分かっているので，この二つ のパラメータをこの範囲に設定した. 今回行った数值解 析では $3 つ の$ 粒径を考慮し，実験データで得られた粒 径分布を基に統一的に変化させた。数值計算はサーマ ルの最大厚さ, フロントの流下速度, サーマル量, 固体 粒子の体積濃度の計算結果を実験結果と比較する。一

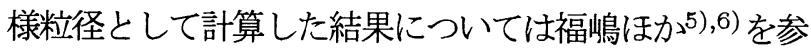
考にされたい.

その結果, 粒径を $0.017 \mathrm{~mm}$ から $0.029 \mathrm{mmm}$ と設定し た場合に実験值を良く再現できることが分かった。そ れらの粒径を用いた場合におりる結果を図 11，12に示 す.これらの図で(a) がサーマルの流下速度, (b) が最 大厚さ，(c) サーマル量, (d) サーマル内の粒子濃度であ る. Run 2(図 11)の場合には粒径 $0.017 \mathrm{~mm}, 0.021 \mathrm{~mm}$, $0.025 \mathrm{~mm}$ の割合は $1: 2: 1$ であった。これらの重み平均の 值として粒径 $0.021 \mathrm{~mm}$ を得るので, この值を用いて均 一粒径として計算を行った. その結果を図中に破線で 示している.

図から分かるように，流下速度，最大厚さ，サーマ ル量, 粒子濃度のいずれも実験誤差の範囲で統一的に 非保存性サーマルの流下特性を表すことができる．ま たRun 2 においては均一粒径として計算しても, 混合 粒径として計算しても, 最大厚さ, 流下速度, サーマ ル量と体積濃度の值には顕著な差は認められない。こ れは計算において与えた粒径の值が狭い範囲に設定し 

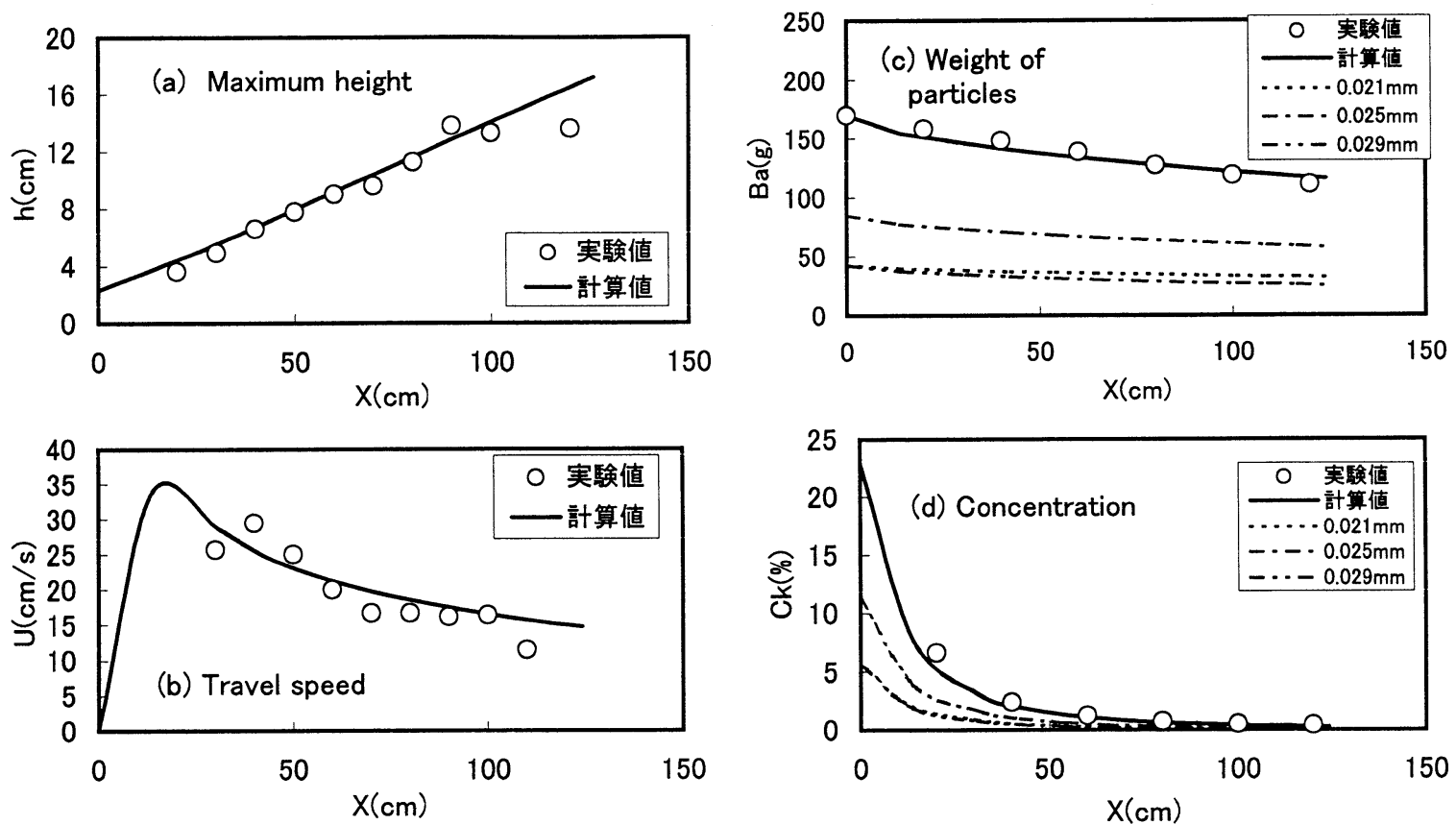

図 12: 計算結果と実験結果との比較 $\left(\operatorname{Run} 4, C_{0}=20 \%, \theta=30^{\circ}, \alpha=0.5, c_{D}=0.5\right)$

たためである.

一方, 傾斜サーマルのフロントの流下速度、最大厚 さ、サーマルによって輸送される硫酸バリウム粒子の 量（サーマル量）と一致させようとするとコールター カウンターで測定した実験結果に比べて, 粒径の大き さをかなり大きくする必要があった. このことから，本 実験においては, 硫酸バリウムの粒子がそれぞれ単独 で沈降するのではなく, 複数の粒子がフロックを形成 して塊となって沈降していることが推測される.また, 粒子の沈降速度以外に固体粒子の粒径の効果について 今後検討する必要がある.

\section{6. おわりに}

非保存性傾斜サーマルの実験において次のような結 果を得た. 硫酸バリウムの初期濃度が $20 \%$ の実験条件 では，粒子の沈降量が多くなり流下速度が早く減速す る。サーマル量は初期濃度が大きくなると，傾斜角の 影響を強く受けるようになる. 硫酸バリウムの粒径分 布は, 傾斜角 $30^{\circ}$ の場合では流下に伴って粒径の大きな 粒子が減少し，小さな粒子が増加寸る傾向にある.

数值計算と実駼結果の比較からは, 連行係数 $\alpha=0.5$ と固定し, $c_{D}=0 \sim 0.5$ の範囲にすることで, 粒子の粒 径として, $D_{s k}=0.017 \mathrm{~mm}$ から $0.029 \mathrm{~mm}$ ほどの粒径 分布を与えれば，浮游傾斜壁面サーマルの流下特性を 統一的に再現することができる. 一方，数值解と実験 結果との比較から求められた粒径は, 硫酸バリウムの 資料をコールターカウンターを用いて求めた粒径に比 べて，かなり大きくなった。逆に実験で測定した粒径 を用いて計算を行うとバリウム粒子の沈降量が少なく なり, サーマル量、バリウム粒子の濃度の流下方向の 変化を説明できなかった.

謝辞 : 本研究の一部は文部省科学研究費補助金基盤
研究 (一般 C) 代表者 福嶋祐介 課題番号 09650563 の補 助を受けたことを記し，深甚なる感謝の意を表します。

\section{参考文献}

1) Beghin, P. and Olagne, X., Experimental and Theoretical Study of the Dynamics of Powder Snow Avalanches, Cold Regions Sci. and Technol., 19, 317356, 1991.

2) 上石勲, 川田邦夫, 密度流による雪崩の運動に関する模 擬実験，雪水， 56-2, 109-118, 1994.

3) 福嶋祐介, 早川典生, 山口武俊, 重力密度流による煙型雪 崩の流動シミュレーションモデルの検討, 雪水, 58-3, 205-214, 1996.

4) 福嶋祐介・金子幸弘，固体粒子を浮游する傾斜サーマル 減速域，水工学論文集，土木学会，41，537-542, 1997.

5) 福鴠祐介・萩原達可, 浮游傾斜サーマルの減速域の流動 特性, 水工学論文集, 土木学会, 42, 517-522, 1998.

6) 福嶋祐介・萩原達司 - 坂本充男, 固体粒子浮游による傾 斜サーマルの流動特性, 水工学論文集, 土木学会, 43 , 893-898, 1999.

7) 福嶋祐介, 粉雪雪崩の流動機構の解析, 雪水, 48-4, 1-8, 1986.

8) Escudier, M. P. and Maxworthy, T., On the Motion of Turbulent Thermals, Jour. Fluid Mech., 61-3, 541$552,1973$.

9) 秋山壽一郎, 浦勝, 齋藤俊一郎, 富岡直人, 傾斜重力密 度流の連行係数に関する統一的考察, ながれ(日本流体 力学会誌), 16-2, 149-161, 1997.

10) Akiyama, J. and Fukushima, Y., Entrainment of NonCohesive Bed into Suspension, External Memorandom, St. Anthony Falls Hydraulic Lab., University of Minnesota, 195, 1985.

11) Garcia, M. and Parker, G., Entrainment of Bed Sediment into Suspension, Jour. Hydraulic Engineering, ASCE, 117-4, 414-435, 1990.

(1999.9.30 受付) 